\title{
A systematic Review of Health Promotion Model for Type 2 Diabetes Prevention
}

\author{
Onanong Bureelerd ${ }^{1 *}$, Chuthamat Baokhumkong ${ }^{1}$, Nopparat Songserm ${ }^{1}$ \\ ${ }^{I}$ (Faculty of Public Health, Ubon Ratchathani Rajabhat University, Ubon Ratchathani Thailand)
}

\begin{abstract}
This research to present the most common quality criteria in health promotion model for type 2 diabetes mellitus prevention. A systematic literature search was conducted to identify review articles, health technology assessments and policy reports of evaluated health promotion interventions in type 2 diabetes mellitus. The articles and researches were searched from the accessible databases such as research in Thailand, Pubmed, CENTRAL, MEDLINE, ScienceDirect, and SciSearch. A quality coding system was developed and included studies were rated independently by three researchers.The experimental and quasi-experimental research designs conducted between the year of 1998 and 2014 were reviewed. A descriptive analysis of study characteristics and evaluation criteria are presented. Fourteen studies were included in the review. Almost all (35.7\%) provided details on participation; however, only $28.6 \%$ reported the coverage of their target population (penetration). Program intensity or implementation as measured by frequency of contacts during first year and intervention duration was identified in all of the reported studies, and $85.7 \%$ of the studies also reported implementation fidelity; however, only $28.6 \%$ of studies employed quality assurance measures to assess the extent to which the program was delivered as planned. Two and $14.3 \%$ of studies reported 'highly' or 'moderately' positive changes (effectiveness) respectively, based on weight loss. Two (14.3\%) studies reported 'high' diabetes risk reduction but 'low' to 'moderate' weight loss only. Our findings identify that program intensity plays a major role in weight loss outcomes. However, programs that have high uptake both in terms of good coverage of invitees and their willingness to accept the invitation can still have considerable impact in lowering diabetes risk in a population, even with a low intensity intervention that only leads to low or moderate weight loss. From a public health perspective, this is an important finding, especially for resource constrained settings. More use of the PIPE framework components will facilitate increased uptake of type 2 diabetes mellitus prevention programs around the world.
\end{abstract}

Keywords: A systematic Review, Health Promotion, diabetes type 2, diabetes.

\section{Introduction}

Type 2 diabetes mellitus constitute a major and growing burden on health care systems globally ${ }^{1}$. People with chronic conditions are their own principal caregivers and health care professionals, regardless of degree of specialization, ought to act as consultants supporting patients in their self-management role. Diabetes is a social problem that demands for re-education and reorientation of health care professionals and health care settings, readiness from policy makers and relevant stakeholders, as well as robust national policies and strategies developed, owned and monitored by national authorities. Health promotion, as defined by the Ottawa Charter for Health Promotion in $1986^{2}$, refers to the process of "enabling people to increase control over, and to improve, their health". In the 4th International Conference on Health Promotion in 1997, The Jakarta Declaration was set out, and gave the following five key prerequisites of success for health promotion strategies ${ }^{3}$ 1) build healthy public policy 2) create supportive environments 3) strengthen community action 4) develop personal skills 5) reorient health services. Health promotion strategies in type 2 diabetes mellitus may consist of one or a combination of programs targeting healthand dietary education, self-management, psychological support, or constitute initiatives targeting health care professionals or community stakeholders, and in addition have an intention to increase partnership across sectors. Also, patient empowerment is an upmost important and central topic in health promotion interventions. Mechanisms that explain success or failure of such initiatives remains mainly unclear or unknown, as there exists no consensus or validated framework to evaluate the structure, process and outcome indicators among complex interventions. Even more so, patient perspectives, experiences, values and preferences are seldom taken into account when it comes to evaluation, as anticipated in health promotion interventions. The overall aim of the systematic literature search was to bring attention to the most commonly used health promotion interventions in type 2 diabetes mellitus, and to provide a deeper understanding of the scope of such interventions and how they are evaluated in order to present quality indicators of good practices. 


\section{Research Objective}

This research aims to present the most common quality criteria in health promotion model for type 2 diabetes mellitus prevention.

\section{Method and Sample size}

\section{Research Methodology}

A systematic literature search was conducted to identify review articles, health technology assessments and policy reports of evaluated health promotion interventions in type 2 diabetes mellitus. The articles and researches were searched from the accessible databases such as research in Thailand, Pubmed, CENTRAL, MEDLINE, ScienceDirect, and SciSearch. A quality coding system was developed and included studies were rated independently by three researchers. The experimental and quasi-experimental research designs conducted between the year of 1998 and 2014 were reviewed.

\section{Data extraction}

A descriptive analysis of study characteristics and evaluation criteria are presented. Three reviewers independently assessed titles and abstracts of all the relevant publications and made decisions on inclusion. Discrepancy in opinion was discussed and no third party was required in the process of study selection. Fulltexts were sought and read for all articles that met the inclusion criteria (except one study that was unavailable in full text ${ }^{4}$. In the case of duplicate reports related to the same study, both articles were evaluated to extract the maximum amount of information. Data was extracted by one author, and checked for accuracy by a second investigator. For each article design, authors and year of publication, as well as type of intervention, evaluation method and reported quality criteria were extracted.

\section{Results}

A detailed PRISMA flow diagram is attached as shown in Fig.1. The initial literature search (October 2014) returned 1,879 publications and 61 additional articles were identified through hand searching of references from the bibliographies of articles identified. Two thousand thirty-nine articles were screened after removing duplicates. An additional 5 articles were included after updating the search until December 2015. A total of 180 articles were assessed for eligibility. A total of 76 articles from 38 studies were included in the review to describe the characteristics of the included studies as shown in Table 1.

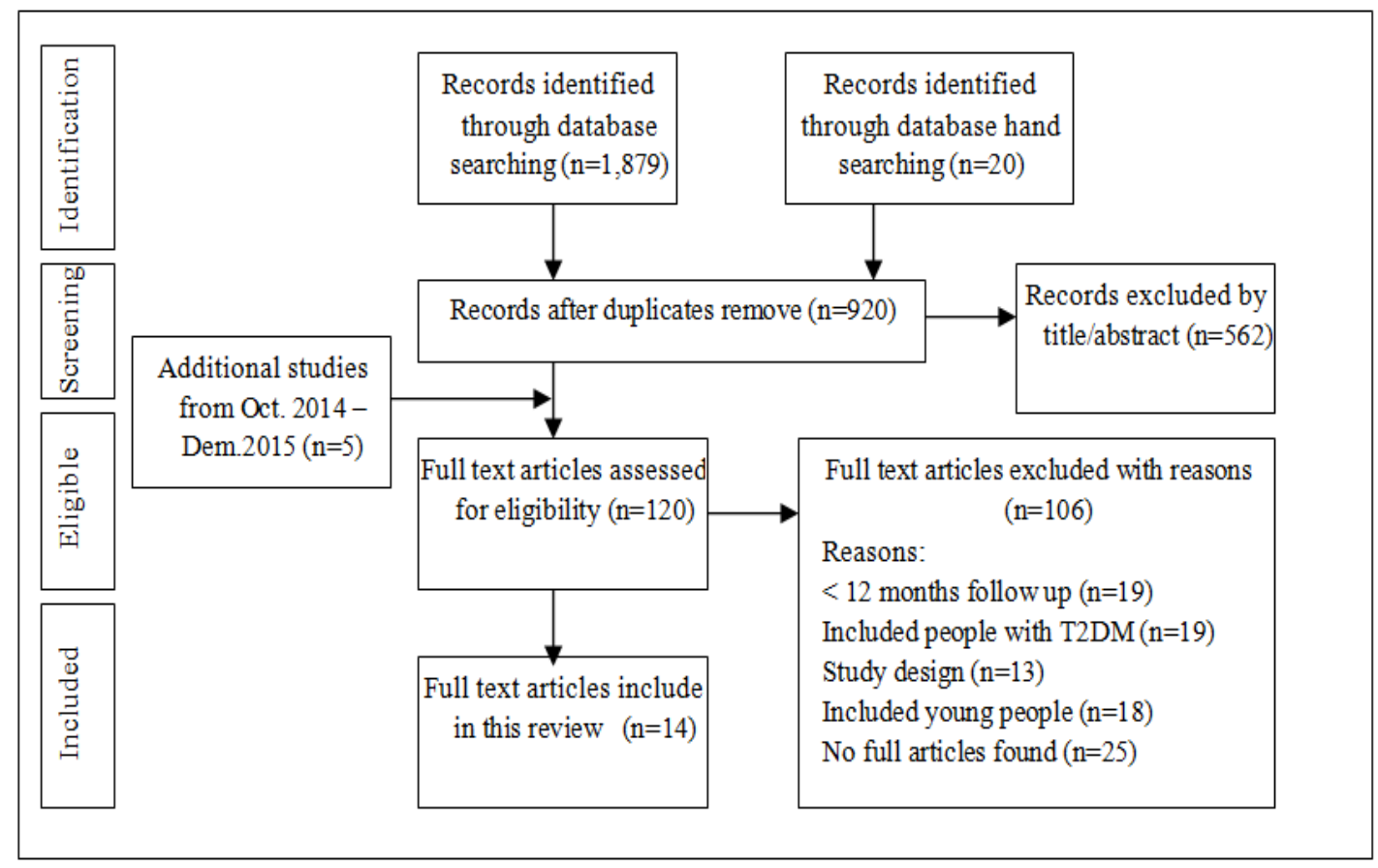

Fig.1- PRISMA flow diagram 
Table 1- Characteristics of the included studies

\begin{tabular}{|c|c|c|c|c|c|c|c|c|}
\hline Year & Author & Study ID & Country & Setting & $\begin{array}{c}\text { Study } \\
\text { population } \\
\end{array}$ & $\begin{array}{l}\text { Sampl } \\
\text { e size }\end{array}$ & $\begin{array}{l}\text { Study } \\
\text { design }\end{array}$ & Intervention \\
\hline 2003 & $\begin{array}{l}\text { Mensin } \\
\mathrm{k} \text { et al. }\end{array}$ & SLIM & Netherlands & Unclear & $\begin{array}{l}\text { Adults at risk of } \\
\text { type } 2 \text { diabetes } \\
\text { mellitus }\end{array}$ & 114 & $\mathrm{RCT}$ & $\begin{array}{l}3 \text { individual and } 1 \text { group } \\
\text { session during } \\
1 \text { year }+ \text { participants } \\
\text { were encouraged to } \\
\text { participate in the } \\
\text { exercise program } 3 \text { times } \\
\text { a year }\end{array}$ \\
\hline 2005 & $\begin{array}{l}\text { Kosaka } \\
\text { et al. }\end{array}$ & $\begin{array}{l}\text { Japanese } \\
\text { DPP }\end{array}$ & Japan & $\begin{array}{l}\text { Hospital } \\
\text {-based }\end{array}$ & Adults with IGT & 458 & RCT & $\begin{array}{l}\text { Detailed instructions on } \\
\text { lifestyle were repeated } \\
\text { every } 3 \text { to } 4 \text { months } \\
\text { during hospital visits }\end{array}$ \\
\hline 2006 & $\begin{array}{l}\text { Oldroyd } \\
\text { et al. }\end{array}$ & $\begin{array}{l}\text { Newcastle } \\
\text { lifestyle } \\
\text { interventio } \\
n\end{array}$ & UK & $\begin{array}{l}\text { Primary } \\
\text { care }\end{array}$ & Adults with IGT & 78 & RCT & $\begin{array}{l}12 \text { individual } 15 \text { - to } 20 \text { - } \\
\text { min review appointments } \\
\text { over } 24 \text { months ( } 6 \text { in the } \\
\text { first } 6 \text { months, } 1 \text { after } \\
9 \text { months and } 5 \text { at } \\
2 \text { monthly intervals } \\
\text { between } 12 \text { and } \\
24 \text { months) }\end{array}$ \\
\hline 2007 & $\begin{array}{l}\text { Absetz } \\
\text { et al. }\end{array}$ & $\begin{array}{l}\text { GOAL } \\
\text { LIT }\end{array}$ & Finland & $\begin{array}{l}\text { Primary } \\
\text { care }\end{array}$ & $\begin{array}{l}\text { Adults at risk of } \\
\text { type } 2 \text { diabetes } \\
\text { mellitus }\end{array}$ & 352 & $\begin{array}{l}\text { Before } \\
\text { and } \\
\text { after }\end{array}$ & $\begin{array}{l}\text { Six 2-hourly group } \\
\text { counselling sessions over } \\
8 \text { months }\end{array}$ \\
\hline 2008 & $\begin{array}{l}\text { Payne } \\
\text { et al. }\end{array}$ & BDPPI & Australia & $\begin{array}{l}\text { Outpatie } \\
\text { nt } \\
\text { setting }\end{array}$ & $\begin{array}{l}\text { Adults at risk of } \\
\text { type } 2 \text { diabetes } \\
\text { mellitus }\end{array}$ & 122 & $\begin{array}{l}\text { Before } \\
\text { and } \\
\text { after }\end{array}$ & $\begin{array}{l}\text { 6-week group self- } \\
\text { management education } \\
\text { program, } 12 \text {-week gym- } \\
\text { or home-based resistance } \\
\text { training, and three } 2 \text {-h } \\
\text { group reinforcement } \\
\text { sessions during } 34 \text {-week } \\
\text { maintenance program }\end{array}$ \\
\hline 2009 & $\begin{array}{l}\text { Kramer } \\
\text { et al. }\end{array}$ & $\begin{array}{l}\text { GLB } \\
(2007- \\
2009)\end{array}$ & USA & $\begin{array}{l}\text { Commu } \\
\text { nity }\end{array}$ & $\begin{array}{l}\text { Adults with pre- } \\
\text { type } 2 \text { diabetes } \\
\text { mellitus }\end{array}$ & 42 & $\begin{array}{l}\text { Before } \\
\text { and } \\
\text { after }\end{array}$ & $\begin{array}{l}12 \text { weekly sessions } \\
\text { ( 60 min) and } \\
\text { participants were offered } \\
\text { the opportunity to attend } \\
\text { monthly support } \\
\text { meetings for } 9 \text { months } \\
\text { after completion of the } \\
\text { intervention }\end{array}$ \\
\hline 2010 & $\begin{array}{l}\text { Vermu } \\
\text { nt et al. }\end{array}$ & $\begin{array}{l}\text { APHRODI } \\
\text { TE }\end{array}$ & Netherlands & $\begin{array}{l}\text { Primary } \\
\text { care }\end{array}$ & $\begin{array}{l}\text { Adults at risk of } \\
\text { type } 2 \text { diabetes } \\
\text { mellitus }\end{array}$ & 925 & RCT & $\begin{array}{l}11 \text { consultations of } 20- \\
\text { min over } 2.5 \text { years, five } \\
1-\mathrm{h} \text { group meetings and } \\
1 \text {-h personal consultation } \\
\text { with the dietician }\end{array}$ \\
\hline 2012 & $\begin{array}{l}\text { Piatt et } \\
\text { al. }\end{array}$ & $\begin{array}{l}\text { GLB } \\
(2005- \\
2008)\end{array}$ & USA & $\begin{array}{l}\text { Commu } \\
\text { nity }\end{array}$ & $\begin{array}{l}\text { Adults with } \\
\text { metabolic } \\
\text { syndrome }\end{array}$ & 105 & $\begin{array}{l}\text { Before } \\
\text { and } \\
\text { after }\end{array}$ & $\begin{array}{l}12 \text { weekly sessions over } \\
12 \text { to } 14 \text { weeks (lasted } \\
29 \text { min) in the groups } \\
\text { of } 5 \text { to } 13 \text { participants }\end{array}$ \\
\hline 2013 & $\begin{array}{l}\text { Jiang et } \\
\text { al. }\end{array}$ & SDPI-DP & USA & $\begin{array}{l}\text { Commu } \\
\text { nity }\end{array}$ & $\begin{array}{l}\text { Adults with pre- } \\
\text { type } 2 \text { diabetes } \\
\text { mellitus }\end{array}$ & 2553 & $\begin{array}{l}\text { Before } \\
\text { and } \\
\text { after }\end{array}$ & $\begin{array}{l}16 \text { group sessions in the } \\
\text { first } 16 \text { to } 24 \text { weeks and } \\
\text { monthly individual } \\
\text { lifestyle coaching } \\
\text { sessions }\end{array}$ \\
\hline 2013 & $\begin{array}{l}\text { Ma J et } \\
\text { al. }\end{array}$ & E-LITE & USA & $\begin{array}{l}\text { Primary } \\
\text { care }\end{array}$ & $\begin{array}{l}\text { Overweight/obe } \\
\text { se adults with } \\
\text { increased } \\
\text { cardiometabolic } \\
\text { risk }\end{array}$ & 241 & RCT & $\begin{array}{l}12 \text { weekly group } \\
\text { sessions }(1.5 \text { to } 2 \mathrm{~h} \text { each) } \\
\text { in the first } 3 \text { months. } \\
\text { From month } 4 \text { to } 15 \text {, } \\
\text { contact every } 2 \text { to } \\
4 \text { weeks depending on } \\
\text { participant needs and } \\
\text { preferences. Individual, }\end{array}$ \\
\hline
\end{tabular}


Table 1- Cont.

\begin{tabular}{|l|l|l|l|l|l|l|l|l|}
\hline Year & Author & Study ID & Country & Setting & Study population & $\begin{array}{l}\text { Sampl } \\
\text { e size }\end{array}$ & $\begin{array}{l}\text { Study } \\
\text { design }\end{array}$ & Intervention \\
\hline 2014 & $\begin{array}{l}\text { Duijzer } \\
\text { et al. }\end{array}$ & SLIMMER & Netherlands & $\begin{array}{l}\text { Primary } \\
\text { care }\end{array}$ & $\begin{array}{l}\text { Adults at risk of } \\
\text { type 2 diabetes } \\
\text { mellitus }\end{array}$ & 31 & $\begin{array}{l}\text { One } \\
\text { group } \\
\text { pre-test } \\
\text { post- } \\
\text { test }\end{array}$ & $\begin{array}{l}\text { In addition to 6 individual } \\
\text { consultations (in total 4 h } \\
\text { per participant), on average, } \\
\text { participants received 5.2 } \\
\text { consultations by dieticians } \\
\text { and 34.1 sports lessons }\end{array}$ \\
\hline 2014 & $\begin{array}{l}\text { Sepah et } \\
\text { al. }\end{array}$ & Prevent & USA & $\begin{array}{l}\text { Online } \\
\text { platform }\end{array}$ & $\begin{array}{l}\text { Adults with pre- } \\
\text { type 2 diabetes } \\
\text { mellitus }\end{array}$ & 220 & $\begin{array}{l}\text { Quasi- } \\
\text { experi } \\
\text { mental } \\
\text { researc } \\
\text { h ondine weekly lessons. } \\
\text { design }\end{array}$ & $\begin{array}{l}\text { Participants were then } \\
\text { offered to continue with a } \\
\text { post-core lifestyle change } \\
\text { maintenance intervention, } \\
\text { with the entire intervention }\end{array}$ \\
\hline 2014 & $\begin{array}{l}\text { Zyriax } \\
\text { et al. }\end{array}$ & DELIGHT & Germany & $\begin{array}{l}\text { Primary } \\
\text { care } \\
\text { (workpla } \\
\text { ce) }\end{array}$ & $\begin{array}{l}\text { Adults at risk of } \\
\text { type 2 diabetes } \\
\text { mellitus }\end{array}$ & 241 & $\begin{array}{l}\text { Before } \\
\text { and } \\
\text { after }\end{array}$ & $\begin{array}{l}12 \text { weekly sessions (for the } \\
\text { first 6 months), 6 monthly } \\
\text { and 6 biweekly sessions (for } \\
\text { the next 6 months). For year } \\
2 \text { and 3 quarterly 1.5-h }\end{array}$ \\
\hline 2015 & $\begin{array}{l}\text { Savas et } \\
\text { al. }\end{array}$ & $\begin{array}{l}\text { IGT care } \\
\text { call }\end{array}$ & UK & $\begin{array}{l}\text { Primary } \\
\text { care }\end{array}$ & $\begin{array}{l}\text { Individuals with } \\
\text { IGT }\end{array}$ & 55 & $\begin{array}{l}\text { Observ } \\
\text { ational } \\
\text { study }\end{array}$ & $\begin{array}{l}\text { A telephone service } \\
\text { providing a } 6 \text { month } \\
\text { lifestyle education program } \\
\text { (20 min } \times 6), \text { in addition to } \\
\text { an introduction call } \\
\text { (10 min) and action } \\
\text { planning call (40 min) }\end{array}$ \\
\hline
\end{tabular}

Studies that met the eligibility criteria for this review were mainly based on either the US-DPP or Finnish-DPS. Seventeen 6 studies were implemented in the USA, 2 in the UK, 2 in the Netherlands, 2 in other European countries, 1 in Australia, and 1 in Japan. There were no studies from low and middle income countries that met our eligibility criteria. The sample size for the participants enrolled in each of these studies ranged between 31 and 2,553 participants. The studies were conducted in a range of settings including primary health care, faith-based, workplace, and other community-based settings. Each study was describes the ratings of all included studies based on the elements of the PIPE Impact Metric as shown in Table 2.

Table 2- Scoring for each PIPE element by study

\begin{tabular}{|c|c|c|c|c|c|c|c|c|c|}
\hline \multirow[t]{2}{*}{ Author Year } & \multirow[t]{2}{*}{ Study } & \multirow{2}{*}{$\begin{array}{l}\text { Penetr } \\
\text { ation }\end{array}$} & \multicolumn{3}{|c|}{ Implementation } & \multirow{2}{*}{$\begin{array}{c}\text { Particip } \\
\text { ation }\end{array}$} & \multicolumn{3}{|c|}{ Effectiveness } \\
\hline & & & Frequency & Duration & Fidelity & & $\begin{array}{c}\text { Success } \\
\text { rate }\end{array}$ & $\begin{array}{c}\text { Weight } \\
\text { loss }\end{array}$ & $\begin{array}{c}\text { Risk } \\
\text { reduction }\end{array}$ \\
\hline $\begin{array}{c}\text { Mensink et al. } \\
2003\end{array}$ & SLIM & High & Low & High & Low & Low & NAC & Moderate & High \\
\hline $\begin{array}{c}\text { Kosaka et al. } \\
2005\end{array}$ & Japanese DPP & NAC & Low & High & Moderate & NAC & NAC & Moderate & High \\
\hline $\begin{array}{l}\text { Oldroyd et al. } \\
2006\end{array}$ & Newcastle LI & NAC & Moderate & High & NAC & Low & NAC & Low & NR \\
\hline $\begin{array}{c}\text { Absetz et al. } \\
2007\end{array}$ & GOAL LIT & NAC & Moderate & Moderate & Moderate & High & NAC & Low & NR \\
\hline $\begin{array}{l}\text { Payne et al. } \\
2008\end{array}$ & BDPPI & NAC & High & High & Moderate & NAC & Moderate & Moderate & NR \\
\hline $\begin{array}{c}\text { Kramer et al. } \\
2009\end{array}$ & $\begin{array}{c}\text { GLB (2007- } \\
2009)\end{array}$ & NAC & High & Moderate & Moderate & Low & NAC & High & $\mathrm{NR}$ \\
\hline $\begin{array}{c}\text { Vermunt et al. } \\
2010\end{array}$ & APHRODITE & NAC & Moderate & High & NAC & Low & NAC & NAC & NR \\
\hline $\begin{array}{c}\text { Boltri et al. } \\
2011\end{array}$ & $\begin{array}{l}\text { DPP (church- } \\
\text { based) }\end{array}$ & NAC & $\begin{array}{l}\text { Low (2 } \\
\text { churches) }\end{array}$ & Low & Moderate & Low & NAC & Low & NR \\
\hline $\begin{array}{c}\text { Piatt et al. } \\
2012\end{array}$ & $\begin{array}{c}\text { GLB (2005- } \\
2008)\end{array}$ & NAC & Moderate & Moderate & Moderate & Low & Moderate & NAC & NR \\
\hline $\begin{array}{c}\text { Jiang et al. } \\
2013\end{array}$ & SDPI-DP & NAC & High & Moderate & Moderate & Low & NAC & Moderate & NR \\
\hline $\begin{array}{c}\text { Ma J et al. } \\
2013\end{array}$ & E-LITE & High & High & High & High & Low & High & High & NR \\
\hline $\begin{array}{c}\text { Duijzer et al. } \\
2014\end{array}$ & SLIMMER & NAC & Low & Moderate & Moderate & Moderate & NAC & Moderate & NR \\
\hline $\begin{array}{c}\text { Sepah et al. } \\
2014\end{array}$ & Prevent & NAC & Moderate & High & Moderate & High & High & NAC & NR \\
\hline $\begin{array}{c}\text { Zyriax et al. } \\
2014\end{array}$ & DELIGHT & High & High & High & Low & Low & NAC & NAC & NR \\
\hline $\begin{array}{l}\text { Savas et al. } \\
2015\end{array}$ & IGT Care Call & NAC & Low & Moderate & High & High & NAC & Moderate & NR \\
\hline
\end{tabular}




\section{Program penetration}

Our analysis shows that only two $(14.3 \%)$ studies reported their estimated target population, from which only seven studies reported the proportion of the target population that was reached with invitations to engage in the program or intervention. Out of these eleven studies, three had 'high', no had 'moderate', and no had 'low' penetration into their target populations as shown in Table 2. Target populations included patients, employees, and church attendees. Each study used various strategies to recruit potential participants including mail invitations, posted flyers, advertising through media, contacting local physicians, local churches, or using intranet or work meetings in the workplace setting.

The three studies that were rated as having 'high' penetration in our analysis applied heterogeneous strategies to reach their target group. Two studies contacted a pre-defined group of people at risk: one at worksite, where all employees who had above average waist circumference were invited for screening ${ }^{4}$, and in the other study ${ }^{5}$ all eligible subjects with high risk for glucose intolerance from a cohort representing general population were contacted. The only study contacted $70 \%$ of the target population for selective screening either by mail or by appointment.

\section{Program implementation}

In order to assess implementation, we evaluated the degree of contact (based on number, length, and type) during the first year of the intervention as frequency; the duration of the entire intervention; and the fidelity of the intervention. All studies in our analysis reported on frequency $28.6 \%$ and duration $57 \%$ of all studies implemented 'high'. In addition, groups led by volunteers as opposed to health care professionals and use of telephone as opposed to face-to-face delivery of individual sessions were also frequently observed adaptations. Only a small proportion (16\%) of studies reported 'low' duration, i.e. intervention delivered over the period of 6 months or less.

\section{Program participation}

The majority of the studies in our analysis $(n=8 ; 57.1 \%)$ reported participation. In fourteen $(65.8 \%)$ of these 9 studies achieved 'low' participation rates. Half of these studies achieved participation rates equivalent to or lower than $10 \%$. Only $4(28.6 \%)$ studies had 'high' participation rates. The only study ${ }^{8}$, participants were recruited by referral from physicians, general practitioners (GPs), or nurses from the participating health facilities and invited to attend a screening clinic. One study recruited participants from online advertisement, seeking individuals with a self-reported clinical diagnosis of prediabetes occurring within the past year; however, recruitment was based on self-selection by participants, which does not reflect a truly random sample ${ }^{9}$.

The only study was scored as having 'moderate' participation, where $57 \%$ available for both penetration and participation, it was observed that 'high' penetration into the target population did not have positive effect on participation. All five studies rated as 'high' penetration in the analysis, reported 'low' participation. Also, none of the seven studies that were rated as 'high' participation provided enough information on reaching out to their target populations, and hence, penetration could not be calculated. However, the information available suggests that the studies where high-risk participants were identified and referred through their GPs or nurses resulted in 'high' participation rates.

\section{Program effectiveness}

Effectiveness was rated based on three criteria: proportion of successful participants; average weight loss; and diabetes risk reduction (absolute/relative). None of the studies reported on all three criteria. Seventeen $(45 \%)$ studies reported the use of intent-to-treat analysis; however, for the purpose of our analysis, effectiveness indicators were considered as presented in each of the studies.

One third $(n=3,21.4 \%)$ of the studies reported the proportion of successful participants who achieved the primary outcome (i.e. $14.3 \%$ weight loss). The proportion of successful participants ranged between 20 and $64 \%$. Six $(42.8 \%$ ) studies reported average weight loss by participants at 12 months, with a range from 0.45 to $7.7 \mathrm{~kg}$. Only 3 of these studies were rated 'high' where average weight loss by participants was more than $4.6 \mathrm{~kg}$. Sixteen (42\%) studies were rated 'low' on the basis of average weight loss of $\leq 2.3 \mathrm{~kg}$ as shown in Table 2.

\section{Discussion}

This is the first systematic review to evaluate the implementation of real-world diabetes prevention programs using the PIPE Impact Metric framework that deploys four highly relevant elements for monitoring program impact in real-world settings. As such, this review complements other recent reviews, e.g. Dunkley et al. $2014^{11}$, by providing a more detailed understanding of key factors underlying successful translation and implementation of diabetes prevention programs in real-world contexts. We have also defined the specific scope of services for calculating the overall costs of services being provided. From both an organizational and societal perspectives, these issues are important to consider since the relative costs and benefits of such services and 
programs are important determinants of their uptake and adoption. Our review of studies published over the last 15 years aims to identify the components of diabetes prevention programs with the highest population impact.

Our review highlights several important findings. First, confirming earlier reviews, our analysis demonstrates that lifestyle-focused diabetes prevention programs that have a 'high' degree of contact have more potential to achieve effective outcomes, especially when measured by weight loss. These programs have typically been based on the US-DPP model and have used a very structured protocol to maximize program fidelity. However, the problem with this approach is that in these studies, program participation tends to be quite low; and furthermore, none of these studies reported diabetes risk reduction.

Second, six of the studies showed different degrees of effectiveness for different outcomes. For example, diabetes risk reduction could be 'high' even when effectiveness in weight loss was 'low' or 'moderate'. Surprisingly, these were all studies of 'low' or 'moderate' frequency, but 'high' duration. This could be very promising especially for settings where intervention resources are constrained but when large populations can be reached by such programs.

Third, we found that 'high' penetration into the target population with invitations to engage prospective participants in the program do not necessarily result in 'high' participation. However, three studies with 'high' penetration resulted in either 'high' weight loss or 'high' diabetes risk reduction. Hence, scalability of the program to reach a large audience appears to be an important ingredient for population-level impact. In summary, while an intensive intervention plays an important role in achieving successful weight loss outcomes, highly scalable moderate- to low-frequency interventions appear to have major potential to achieve diabetes risk reduction in populations. We found estimates of target populations to be reported by less than one third of included studies. Hence, it is possible that many of these programs were delivered to highly selected populations which limit their generalizability. The research found that adherence to guidelines on the content and delivery was significantly associated with a greater weight loss. Our findings on the potential of 'low' to 'moderate' frequency interventions with longer duration to achieve significant risk reduction support earlier findings ${ }^{12-13}$. A recent CPSTF review ${ }^{14}$ shows lower weight loss than the US-DPP but still concluded strong evidence of effectiveness.

Examining the implementation component further, in calculating 'frequency', we have used contacts made in the initial 12 months only because most of the studies did not extend beyond 12 months. In those that did, the initial 12 months can be considered as the 'action' phase, bringing about the lifestyle changes, and beyond that is a follow-up and maintenance phase, which some studies support with less frequent contacts. In translational research, a systematic evaluation of program fidelity is important to assess the extent to which program was implemented as designed. We based our definition of fidelity on whether a standard curriculum was used to guide the delivery of intervention and whether quality assurance measures were placed to monitor the implementation of the intervention. Not many studies clearly reported whether the quality assurance measures were able to guarantee 'high' fidelity, this clearly being one of the next important steps in program development. This needs to be examined in future studies.

The PIPE Impact Metric elements are interrelated in that participation is always a proportion of penetration and effectiveness can only be attributed to those who participated. Effectiveness, in this context, is defined as the number or proportion of participating cases who reached a priori defined success criterion. In prevention of T2DM, diabetes risk reduction is one such success criterion. In many studies, however, weight loss was also a main outcome either in individual cases as a percentage of overall body weight or across a population as an average percentage of weight loss. In our review, we used either criterion diabetes risk reduction or weight loss to assess effectiveness.

However, examination of studies with 'low' effectiveness reveals that for some of the studies the reported changes in weight loss were very small. Some of these studies reported a significant reduction in weight following the active intervention phase, but the weight was partly or, in some studies, entirely regained by the end of 12 months. Lack of consistency in the way weight loss outcomes are reported and analysed needs to be addressed in future translational research ${ }^{15}$.

Our review includes diabetes prevention translational programs published since 2001 and until 2015. The studies included in this review have implemented 'high' (34\%), 'moderate' (37\%), and 'low' (29\%) frequency interventions; however, we noticed that most of the 'low-frequency' interventions were conducted in earlier years, whereas, designing 'moderate' to 'high' intensity interventions occurred in more recent years. However, 'participation' has been consistently low in a majority of the studies over the last 15 years. One of the reasons for this may be the fact that program planners focus on the content of the interventions instead of balancing the content with the experience of the participant that is, on the 'participation' dimension and the engagement factor that connects the participant with the intervention.

Future translational research in this field needs to invest in designing recruitment more carefully to ensure high program reach; examining factors that optimize engagement and retention in the structured lifestyle programs; and maximizing adherence to the long-term behavior changes ${ }^{16}$. 


\section{Acknowledgments}

The authors thank the publication arises from the research in Thailand, Pubmed, CENTRAL, MEDLINE, ScienceDirect, and SciSearch., which has received funding from the framework of the Health Programe. Sole responsibility lies with the authors and the Consumers, Health, Agriculture and Food Executive Agency is not responsible for any use that may be made of the information contained therein and as a results this study with great success.

\section{References}

[1] International Diabetes Federation. IDF diabetes atlas. Brussels, Belgium: International Diabetes Federation; 2013.

[2] World Health Organization. The Ottawa charter for health promotion: first international conference on health promotion, Ottawa, 21 November 1986. Available from: www.who.int/healthpromotion/conferences/previous/ottawa/en/.

[3] The Jakarta declaration on leading health promotion into the 21st century. Health Promot Int 1997;12(4):261-4.

[4] Zyriax BC, Letsch B, Stock S, Windler E. DELIGHT (delay of impaired glucose tolerance by a healthy lifestyle trial) a feasibility study on implementing a program of sustainable diabetes prevention in German companies. Experimental and clinical endocrinology \& diabetes: official journal, German Society of Endocrinology [and] German Diabetes Association. 2014;122(1):2035. Mensink M, Feskens EJ, Saris WH, De Bruin TW, Blaak EE. Study on lifestyle intervention and impaired glucose tolerance Maastricht (SLIM): preliminary results after one year. International journal of obesity and related metabolic disorders: journal of the International Association for the Study of Obesity. 2003;27(3):377-84. doi: 10.1038/sj.ijo.0802249.

[5] Ma J, Yank V, Xiao L, Lavori PW, Wilson SR, Rosas LG, et al. Translating the diabetes prevention program lifestyle intervention for weight loss into primary care: a randomized trial. JAMA internal medicine. 2013;173(2):113-21. doi: 10.1001/2013.jamainternmed.987.

[6] Absetz P, Valve R, Oldenburg B, Heinonen H, Nissinen A, Fogelholm M, et al. Type 2 diabetes prevention in the "real world": oneyear results of the GOAL implementation trial. Diabetes Care. 2007;30(10):2465-70. doi: 10.2337/dc07-0171.

[7] Savas LA, Grady K, Cotterill S, Summers L, Boaden R, Gibson JM. Prioritising prevention: implementation of IGT care call, a telephone based service for people at risk of developing type 2 diabetes. Primary care diabetes. 2015;9(1):3-8. doi: 10.1016/j.pcd.2014.07.003.

[8] Sepah SC, Jiang L, Peters AL. Translating the diabetes prevention program into an online social network: validation against CDC standards. The Diabetes educator. 2014;40(4):435-43. doi: 10.1177/0145721714531339.

[9] Duijzer G, Haveman-Nies A, Jansen SC, ter Beek J, Hiddink GJ, Feskens EJ. Feasibility and potential impact of the adapted SLIM diabetes prevention intervention in a Dutch real-life setting: the SLIMMER pilot study. Patient education and counseling. 2014;97(1):101-7. doi: 10.1016/j.pec.2014.05.024.

[10] Dunkley AJ, Bodicoat DH, Greaves CJ, Russell C, Yates T, Davies MJ, et al. Diabetes prevention in the real world: effectiveness of pragmatic lifestyle interventions for the prevention of type 2 diabetes and of the impact of adherence to guideline recommendations: a systematic review and meta-analysis. Diabetes care. 2014;37(4):922-33. doi: 10.2337/dc13-2195.

[11] Pronk NP, Remington PL; Community Preventive Services Task Force. Combined diet and physical activity promotion programs for prevention of diabetes: community preventive services task force recommendation statement. Ann Intern Med. 2015 ; 163. doi:10.7326/M15-1029.

[12] Ali MK, Echouffo-Tcheugui J, Williamson DF. How effective were lifestyle interventions in real-world settings that were modeled on the diabetes prevention program? Health affairs. 2012;31(1):67-75. doi: 10.1377/hlthaff.2011.1009.

[13] Johnson M, Jones R, Freeman C, Woods HB, Gillett M, Goyder E, et al. Can diabetes prevention programmes be translated effectively into real-world settings and still deliver improved outcomes? A synthesis of evidence. Diabetic medicine : a journal of the British Diabetic Association. 2013;30(1):3-15. doi: 10.1111/dme.12018.

[14] Whittemore R. A systematic review of the translational research on the diabetes prevention program. Translational behavioral medicine. 2011;1(3):480-91. doi: 10.1007/s13142-011-0062-y.

[15] Spring B, Sohn MW, Locatelli SM, Hadi S, Kahwati L, Weaver FM. Individual, facility, and program factors affecting retention in a national weight management program. BMC public health. 2014;14:363. doi: 10.1186/1471-2458-14-363.

[16] Kosaka K, Noda M, Kuzuya T. Prevention of type 2 diabetes by lifestyle intervention: a Japanese trial in IGT males. Diabetes research and clinical practice. 2005;67(2):152-62. doi: 10.1016/j.diabres.2004.06.010.

[17] Oldroyd JC, Unwin NC, White M, Mathers JC, Alberti KG. Randomised controlled trial evaluating lifestyle interventions in people with impaired glucose tolerance. Diabetes Res Clin Pract. 2006;72(2):117-27. doi: 10.1016/j.diabres.2005.09.018.

[18] Payne WR, Walsh KJ, Harvey JT, Livy MF, McKenzie KJ, Donaldson A, et al. Effect of a low-resource-intensive lifestyle modification program incorporating gymnasium-based and home-based resistance training on type 2 diabetes risk in Australian adults. Diabetes Care. 2008;31(12):2244-50. doi: 10.2337/dc08-0152.

[19] Kramer MK, Kriska AM, Venditti EM, Miller RG, Brooks MM, Burke LE, et al. Translating the diabetes prevention program. A comprehensive model for prevention training and program delivery. American Journal of Preventive Medicine. 2009;37(6):505-11. doi: 10.1016/j.amepre.2009.07.020.

[20] Vermunt PW, Milder IE, Wielaard F, van Oers JA, Westert GP. An active strategy to identify individuals eligible for type 2 diabetes prevention by lifestyle intervention in Dutch primary care: the APHRODITE study. Family practice. 2010;27(3):312-9. doi: 10.1093/fampra/cmp100.

[21] Piatt GA, Seidel MC, Chen H-Y, Powell RO, Zgibor JC. Two-year results of translating the diabetes prevention program into an urban, underserved community. Diabetes Educator. 2012;38(6):798-804. doi: 10.1177/0145721712458834.

[22] Jiang LH, Manson SM, Beals J, Henderson WG, Huang HX, Acton KJ, et al. Translating the diabetes prevention program into American Indian and Alaska native communities results from the special diabetes program for Indians diabetes prevention demonstration project. Diabetes Care. 2013;36(7):2027-34. doi: 10.2337/dc12-1250. 